Nadwa : Jurnal Pendidikan Islam

Vol. 12, Nomor 1 Tahun 2018

Accredited by Ristekdikti based on Decree No. 51/E/KPT/2017

\title{
Model of Islamic Religion Education 435 Based on Islam Nusantara on College
}

\author{
Umi Zulfa \\ Imstitut Agama Islam Ghazali (IAIG) Cilacap \\ umi.zulfa@iaiig.ac.id
}

\begin{abstract}
This paper aims to provide an alternative model of Islamic Religion Education Based on Islam Nusantara on College, that make students able to emerge as wise leaders in the midst of Indonesian society and far from being exclusive. This research used qualitative approach with type of research library. The result sawn that Islamic Religion Education model of Islam Nusantara in college is built from 435 Islam Nusantara concept that is a model consisting of four (4) character, they are spirit of religious education process. Namely: ruuhuddin (religious spirit), nationalism, ruuhudta'addudiyah (spirit of diversity) and ruuhul insaniyyah (spirit of humanity), built on 3 main pillars: thought (fikrah), movement (harakah), real action (amaliyyah), and with 5 markers, namely islakhiyyah, tawazunniyah, tatawwuniyah, akhlaqiyah, and tasamuh..
\end{abstract}

Keywords: Islam Nusantara; Islamic Religion Education; College;

\begin{abstract}
Abstrak
Tulisan ini bertujuan untuk memberikan model alternatif Pendidikan Agama Islam Berbasis Islam Nusantara di Perguruan Tinggi, yang membuat siswa mampu tampil sebagai pemimpin yang bijaksana di tengah masyarakat Indonesia dan jauh dari eksklusif. Penelitian ini menggunakan pendekatan kualitatif dengan jenis perpustakaan penelitian. Hasil penelitian menunjukkan bahwa model Pendidikan Agama Islam Islam Nusantara di perguruan tinggi dibangun dari 435 konsep Islam Nusantara yaitu model yang terdiri dari empat (4) karakter, yaitu semangat proses pendidikan agama. Yakni: ruuhuddin (semangat agama), nasionalisme, ruuhudta'addudiyah (spirit of diversity) dan ruuhul insaniyyah (semangat kemanusiaan), dibangun di atas 3 pilar utama: pemikiran (fikrah), gerakan (harakah), aksi nyata (amaliyyah), dan dengan 5 penanda, yaitu islakhiyyah, tawazunniyah, tatawwuniyah, akhlaqiyah, dan tasamuh.
\end{abstract}

Kata Kunci: Islam Nusantara; Pendidikan Agama Islam; Pendidikan Perdamaian, Pendidikan tinggi 


\section{Introduction.}

Indonesia care about religious issues and religious education citizens, even religious education becomes the subject to learners from elementary, middle and high level of education. At higher education level, religious education based on Law No. 12 of 2012 on Higher Education Article 35 paragraph 3 as a compulsory subject taught along with three other subjects, namely Pancasila, Civic Education and Indonesian Language. On the other hand, the worrying phenomenon is the emergence of radicalism in the name of religion, even on campus. the results of research Abdullah Dawn et al quite surprising about the attitude of students at some of Indonesia's top universities. They tend to agree to radicalize on behalf of Amar Ma'ruf Nahi Nahi Munkar in the form of sweeping to places of immorality with numbers reaching 65\% (1594 respondents)1.

Situations like this certainly cannot be left. Moreover, students who in fact become the next generation of potential nation to be the leader of the nation, they should appear as a potential leader who can show tolerant attitude in the midst of many diversity both in Indonesia and in the world.

Therefore, this paper will discuss the model of alternative religious education in college. The new concept of Islamic Religion Education Model Based on Islam Nusantara on College with the formulation 435 . Where four (4) are enthusiastic spirit of religious education process, namely: ruuhuddin (religious spirit), nationalism, ruuhudta'addudiyah (spirit of diversity) and ruuhul insaniyyah (spirit of humanity)2. built on 3 main pillars: (Fikrah thought (Fikrah), movement (harakah), real action (amaliyyah) 3 , and with 5 markers, namely islakhiyyah, tawazunniyah, tatawwuniyah, akhlaqiyah, and tasamuh.

Islamic Religion Education (IRE) based on Islam Nusantara is an education that have spirit of providing an alternative model

1 Andik Wahyun Muqoyyidin, Membangun Kesadaran InklusifMultikultural Untuk Deradikalisasi Pendidikan Islam, Jurnal Pendidikan Islam Vol.II, Noor 1, Juni 2013/1434. Hlm.134.

2 Ibnu hazen (ed), 100 Ulama Dalam Lintas Sejarah NU, (Jakarta:

Lembaga Ta'mir Mesjid -PBNU, 2015). Hlm.x

3 Ibnu hazen (ed),100 Ulama dalam Lintas ...hlm.328-329

4 Ibnu hazen (ed), 100 Ulama dalam Lintas ... hlm.328-329 
of religious education to answer the challenges of society postmodernism. Therefore, the model of religious education is a very fundamental issue regardless of the attitude of pro and contra against the term Islam Nusantara. The idea of IRE based Islam Nusantara is one of the efforts to renew the concept and model of Islamic educational thinking, especially in the archipelago in the aspect of higher education. The ultimate goal (learning outcomes) on higher education based on Dikti Formulations as follows:

The formation of the student's personality as a whole (kaffah) by making Islam as the foundation of thinking, acting and behaving in the development of science and profession. It means that a whole personality can only be realized if in every student self-implanted faith and piety to Allah swt. It should be noted, however, that faith and piety, will only be realized if it is supported by elements, namely: insight / knowledge of Islam (Islamic knowledge), religious dispositions, Islamic skills, (Islamic commitment), confidence as a Muslim (Moslem confidence), and skills in implementing religious teachings (Islamic competence)s.

What is the ultimate goal of the IRE based Islam Nusantara on college, in line with the Islamic Nusantara like in Islamic boarding schools, namely Islam as the basis of thought (fikrah), attitude (harakah) and behave (amaliyah). Based on this condition, writer is hoped that this paper will contribute to the efforts of the affirmation of Islam Nusantara that will deliver Indonesia as a better country and more tolerant relationship (Tasamuh), polite (Akhlaqiyyah) and humane (Insaaniyyah) and justice (Ta'addul). This research used qualitative approach, type of literature research especially in the field of education. In the opinion of McMillan and Schumacher6 Data obtained from

5 Direktorat Jenderal Pembelajaran dan Kemahasiswaan Kementrian Riset, Teknlogi dan Pendidikan Tinggi R I, Pendidikan Agama Islam untuk $P T$, 2016. Cetakan 1, hal. i

6 Schumacher, James H McMillan and Sally.2001. Research In Education. A Conceptual Introduction. New York: Addison Wesley Longman.Inc. 
literature sources using the documentary method 7 and analyzed by using content analysis 8 .

\section{Islam Nusantara}

Islam Nusantara is Islam taught by Walisongo, that is peaceful Islam, get along, not arrogant and rahmatan lil 'Alamin, brought by Walisongo which they understand from the teachings of Prophet Muhammad saw., with not only invites bil lisan, but also bil hal, not only concern formalities, but also the core of Islamic teachings. This means a typical Islamic style of Indonesia, which is a combination of Islamic theological values with the values of local traditions, cultures, and customs in the country. In simple language, Islam Nusantara is the same Islamic concept as Islam elsewhere, but in understanding, its application and its application contextually (bound to the dimension of time and place). As a concept, Islam Nusantara has special characteristics that distinguish it from others Islam. There are at least two concepts that are carried by Islam Nusantara, namely pillars, markers or characteristics. First, 3 (three) Pilar Islam Nusantara, namely: thinking (fikrah), movement, action. Second, the 5 Islamic bookmarks of the archipelago, namely: reform (islahiyyah), balanced (tawazuniyyah), voluntary (tatawwu'iyyah), polite (akhlaqiyyah) and tolerant (tasamuh)9.

The following table presents about 8 pillars and markers / special characteristics of Islam Nusantara.

Pillars and Characteristics of Islam Nusantara

\begin{tabular}{llrl}
\hline \multicolumn{1}{c}{ Pillars } & \multicolumn{1}{c}{ Characteristics } \\
\hline$>\begin{array}{l}\text { Fikrah-Tawassuth The } \\
\text { thought (fikrah) of Islam } \\
\text { Nusantara is tawassuth. This }\end{array}$ & $>$ & $\begin{array}{l}\text { Islakhiyyah. Reformation } \\
\text { (islahiyyah). That, thoughts } \\
\text { based on development (tatwir }\end{array}$ \\
\hline
\end{tabular}

7 Zulfa, Umi. 2011. Metodologi Penelitian Sosial. Edisi Revisi.

Yogyakarta: Cahaya Ilmu.

8 Muhadjir, Noeng.2000. Metodologi Penelitian Kualitatif. Yogyakarta: Rake Sarasin.

9 Ibnu hazen (ed), (2015), 100 Ulama Dalam Lintas Sejarah NU, (Jakarta: Lembaga Ta'mir Mesjid -PBNU, 2015). Hlm.328-329 


\begin{tabular}{|c|c|c|}
\hline & $\begin{array}{l}\text { means that the way of } \\
\text { thinking that put forward } \\
\text { Islam Nusantara is moderate } \\
\text { (tawassuth), which is not } \\
\text { textual position, but also not } \\
\text { liberal }\end{array}$ & $\begin{array}{l}\text { al fikrah), and therefore, } \\
\text { Islamic thought archipelago is } \\
\text { a thought aimed at continuous } \\
\text { improvement, the way of } \\
\text { dynamic thinking. }\end{array}$ \\
\hline$D$ & $\begin{array}{l}\text { Harakah-movement, that } \\
\text { carried Islam Nusantara as a } \\
\text { movement to make } \\
\text { improvements for the } \\
\text { association and its citizens. } \\
\text { There are not only based on } \\
\text { the tradition but also } \\
\text { innovation. }\end{array}$ & $\begin{array}{l}\text { Tawazuniyyah. which means } \\
\text { balanced in all fields. If a } \\
\text { movement is implemented, then } \\
\text { the balance aspect must also be } \\
\text { taken into consideration. This } \\
\text { tawazuniyyah weighs with justice. } \\
\text { If a movement is implemented, } \\
\text { then the balance aspect must also } \\
\text { be taken into consideration. This } \\
\text { Tawazuniyyah weighs with } \\
\text { justice. }\end{array}$ \\
\hline
\end{tabular}

Amaliah. or actual action of Islam Nusantara is based on fikh and ushul fikh, that is taking care of tradition ('urf and' adat) based on Islamic value
3.Tatawwuniyah means volunteer (volunteerism). One thing that must be held in this volunteer is in carrying out thoughts; movements, and practices, nahdliyin should not impose on others.

Courteous (akhlaqiyyah), ie all forms of thought, movement and practice of Islam Nusantara Muslims performed with polite. The fee here applies in accordance with social ethics, and state and religion.

Tasamuh, which means being tolerant, respectful to others. This tolerant attitude is not passive, but critical and innovative.

\section{The Policy of Islamic Education In College}

Islam Nusantara in its execution can be done through an educational path, influenced by the thought of Al Ghazali 
especially tasawuf, with the characteristics of his teachings is polite and reduce the dose of formalism-legalism in the body of Muslims10. This pattern can be used as moral education (Islam) in Indonesia, especially formal education such as college. Thus, the college able to produce output that always appreciates the differences and pluralism of the community.

The government itself through several regulations have made arrangements on religious education (Islam), especially in Higher Education, including:

1. Law N0. 20 of 2003 on National Education System, article 1511, mentions "type of education, including general, vocational, academic, professional, vocational, religious, and special education".

2. Law No. 12 the year 2012 on Higher Education, Article 35 paragraph 3 "The curriculum of higher education shall contain the subjects of Religion, Pancasila, Civic Education, and Bahasa Indonesia for undergraduate and diploma programs"12.

3. Government Regulation No. 55/ 2007 on Religious Education and Religious Education article 1, paragraph 113, explains the limits of religious education: "Religious education is education that provides knowledge and shapes the attitude, personality, and skills of learners in the practice of religious teachings, which implemented at least through the subjects on all paths, levels, and types of education ". The article 5, paragraph 1 "the religious education curriculum must be implemented in accordance with the National Education Standards".

10 Abdul Moqsith Ghazali, “ Tasawuf Al Ghazali dalam Ihya' 'Ulum Al Din", makalah Seminar Nasional Imam Ghazali: "Pemikiran dan Pengaruhnya Terhadap Islam Nusantara dan Peradaban Dunia", IAIIG Cilacap pada tanggal 3 April 2016.

11 UU No.20 tahun 2003, 'pasal 15

12 UU N0.12 Tahun 2012, pasal 35 ayat 3

13 PP. No.55 tahun 2007, pasal 1 ayat 1 
4. Regulation of the Minister of Research, Technology and Higher Education no. 44 of 2015 on National Standards of Higher Education 14.

5. Circular Letter of the Directorate General of Learning and Student Affairs no. 435/B/SE/2016 on the Materials of Compulsory Subjects of the General Compulsory Course, "Directorate General of Learning and Student Affairs has compiled a Textbook of Subjects for Religious Subjects, Pancasila, Civics and Indonesian Education in order to enrich the Materials. in order to face the era of globalization and the ASEAN Economic Community (MEA) capable of delivering students to be adaptive, competitive, and become a graduate who love the homeland, ready to defend the country, and able to improve the identity of his nation " 15 .

\section{Characteristics of Islamic Religious Education in College}

The implementation of religious education in college certainly has its own characteristics. At least when viewed from the main duties and functions of religious education at college.

1. There are five main tasks of education (religion) of Islam in the college according to Amin Abdullah16. Namely : a) introduces contemporary issues facing Muslims, together with the attempt to explain classical Islamic teachings, b) directing the ultimate goal of Islam on solving problems of human relationships, c) contextualize Islam, d) criticizing the emphasis of religious education only on cognitive domains, and f) dedicating Islam is not solely for the development of individual morality, but also public morality.

2. The function of religious education according to Nurul Zuriyah. there are two functions, namely conservative

${ }_{14}$ Peraturan Mentri Riset, Teknologi dan Pendidikan Tinggi Nomo2 44 tahun 2015

15 Surat Edaran Direktorat Jenderal Pembelajaran dan Kemahasiswaan Nomor 435/B/SE/2016

16 Mahmud Arif, Pendidikan Agama Islam Inklusif-Multikulturalisme, Jurnal Pendidikan Islam Vol.1 N0.1, Juni 2012/1433, hal: 11 
function and progressive function17. Conservative function is the function of inheritance and the preservation of the ideals and culture of a society in the next generation, where religion as a source of cultural development inspiration. While the progressive function is how religious education activities can provide knowledge and development stock, the planting of values based on religion and the provision of skills to anticipate the future so that the next generation has the provision of the ability to face the challenges of the present and the future.

To be able to run the duties and functions, then the IRE in the college need to refer to some opinions such as Hujjatul Islam Imam Al Ghazali. Citing the opinion of $\mathrm{Al}$ - Ghazâlî quoted Abdul Halim Mahmud about the purpose of learning is "The result of science is actually closer to God, the God of nature, and connecting with high angels and gathered with the spirits of nature. All that is grandeur and respect is instinctive"18. This means that IRE is also oriented to get closer to Allah swt.. Therefore, students as learners who must meet the requirements as proposed by $\mathrm{Al}$ Ghazali19 as follows:

1. Must be clean spirited, avoided from bad manners and other disgraceful properties such as, anger, hurt, envy, high heart, ujub, takabbur and others.

2. Must reduce its attachment to the world that interfere with the smoothness of mastery of science.

3. Must be tawadlu against his teacher.

4. Learning gradually

5. Recognize the value of the knowledge

17 Nurudin, Perbandingan Pengelolaan Pendidikan Agama Pada Sekolah di Indonesia dan Sekolah Republik Indonesia Tokyo, Jurnal Pendidikan Islam. Vol.IV.Nomor 1, Juni 2015/1436, hal.9 18 Asep Hermawan, Konsep Belajar dan Pembelajaran Menurut Al Ghazali, Studia Didaktika, Jurnal Ilmiah Pendidikan, Vol.10 N0.1 tahun 2016, hal.100

19 Al Wizar, Pemikiran Pendidikan Al Ghazali, Jurnal Potensia Vol.14 Edisi 1 Januari-Juni 2015, Hal 140-141 
Furthermore, in addition to student conditioning, the curriculum of IRE in IRE according to Al Ghazali,20 oriented as a religion that serves as a means to purify themselves and clean it from the influence of world life, as well as a science that gives the benefit of the world and the hereafter (pragmatictheological).

\section{Islamic Education Based Islamic Nusantara at College}

1. Inclusive Education.

Inclusion or inclusive is one of the strategies that can be applied in implementing IRE in on higher education. The main philosophies and principles promoted in inclusive education are 1) inclusion is a human rights and equality issue, not merely a special educational issue, 2) inclusion is appreciating even celebrating the differences in the diversity of their identity and learning needs, 3 ) inclusion aims not to mainstream learners in an unchanged system. In contrast, inclusion aims to change the system in order to meet the needs of learners and 4) inclusion should be communitybased. That is, an inclusive education institution reflects how the community around it. In other words, an inclusive system can be realized only through the establishment of an inclusive and democratic society the community around it. In other words, an inclusive system can be realized only through the establishment of an inclusive and democratic society 21.

Inclusive IRE at college will be present as a form of the student inclusiveness representation as well as result of a way of thinking, attitude, and behavior of student inclusive to the existence of other religion and other differences.

The IRE inclusive in higher education should be implemented under the following conditions: (a). built on freedom of expression and the distinction should be appreciated not muzzled. (b). Built on the character of the learner who puts humility, generosity, friendliness, and

20 Ibid, hal.144-145

21 Akhmad Soleh, Kebijakan PT Negeri Yogyakarta Terhadap Penyandang Disabiltas, Jurnal Pendidikan Islam Vol.III Nomor 1, Juni 2014/1435, hlm. 13 
courtesy in respect for others. (c). Built on a humble attitude recognizes the limitations of human beings in achieving absolute truth. (d). Promote a process that encourages learners to see the opinions of others as the respectful, creative and independent dimension. (e). Emphasizes the importance of emotional control in addressing differences 22.

\section{Multicultural education}

Multicultural education is an effort to realize the spirit of the flow or understanding of multiculturalism, whose emergence began with the development of ideological movement or understanding of multiculturalism in Western countries such as the US, Britain, Canada, and Australia as a movement politics of difference 1950- a sd-1660s 23. The spirit of multicultural education is the recognition of the dignity of human beings living in their communities with their unique culture.

\section{Peace Education (PE)}

Peace Education is an educational concept that has emerged since the time of Comenius and has grown more and more in the later years of the twentieth century. Peace Education is essentially a process of gaining knowledge, attitude development, and behavior to live in mutual respect, tolerance, peace, mutual aid, and nonviolence 24.

In practice, Peace Education relies on the three Peace Education PE pillars of educators, learners and parents 25. All three have their respective roles as well as active actors in the planting of noble values in building peace. Educators serve as educators of values and science. Learners act as successors and peers for peers. While parents act as partners of teachers to encourage, support and develop the actualization or implementation of a culture of peace without violence.

22 Irwan Maduqi, Deradikalisasi Pendidikan Islam Berbasis Khasanah

Pesantren, jurnal Pendidikan Islam Vol.1, Juni 2013/1434, hlm.10-12.

23 Imam Machali, Peace Education Dan Deradikalisasi Agama, Jurnal Pendidikan Islam Vol.II, N0 1, Juni 2013/1434. hlm. 48-49

24 Imam Machali, Peace Education ...hlm. 44-47.

25 Imam Machali, Peace Education ...hlm. 46 
4. Institutionalization. IRE learning will have full strength if the values. This stage, make values in the IRE become a strong identity and character for students and all components in the college. This process is carried out through three (3) stages, namely (a) the stage of rulemaking, i.e. the approval of the rules to be followed by all campus community agreed by the family/community. (b) The stage of day-to-day practice: implementing/practicing the rules at a point an in day-to-day activities and (c) the formalization stage of institutional cultural symbols, i.e. formalizing the value symbols that all campus communities should support: community symbols, clothing, and other attributes26.

This learning model is called IRE-Based Islamic Nusantara Model because this learning model is a model of IRE learning which is based on Islamic Nusantara especially in college that is very heterogeneous society. While referred to as Learning Model IRE 435. This model is formulated from the 435 Islamic Nusantara formula, which is 4 (four) spirit, 3 pillars and 5 markers of Islam Nusantara. Plus formula 4 special education, i.e. inclusive education, multicultural education and peace education (peace education). 27

The realization of IRE learning at such a college will become a pioneer for the realization of a world full of peace and prosperity in Ridlo Allah swt.. IRE able to contribute mature values to realize a future society of prosperity, peace and lead to increased adherence to Him. This is relevant to Mulyadhi Kartanegara Kartanegara said that there are civil values that support the upholding of the cosmopolitan society, namely:

1. Inclusivism, ie self-disclosure of "external elements" through the ability to appreciate and select constructively.

26 Umi Zulfa, Model Pembelajaran Unggulan, Cilacap: Ihya Media, Tahun 2017, Hal 243-245

27 Inovation of Islamic Religios Education also have been application in elementary school (SDIP) kroya. Look at article Umi Zulfa, " Model Pembelajaran :SICI" Alternatif Model Pembelajaran IRE Unggulan”, Nadwa. Volume 7.Nomor 1, April 2013: 118-123. 
2. Humanism, in the sense of view that treats humans solely because of their humanity, not because of other causes outside it, such as race, caste, wealth, and religion. Included in humanism here is an egalitarian nature that views human beings equal in degree.

3. Tolerance, namely the existence of the extinction and greatness of the soul in addressing the differences.

4. A democracy that gives space for freedom of thought and the delivery of criticism.

\section{Conclusion}

The Islamic Religion Education (IRE) is an important and fundamental part of the national education system in the context of Indonesia's diversity and the world community. The Islamic Religion Education (IRE) is an important and fundamental part of the national education system in the context of Indonesia's diversity and the world community. Indonesia required religious education design that is not only able to reduce the potential for conflict but also able to make human life on earth is full of peace and prosperity. Therefore, with the emergence of IRE based Islam Nusantara on college or can be called Learning Model IRE 345, is expected to be an alternative to create human life in the state and the world peacefully so that the welfare of human life can be achieved in the correct sense.

\section{References}

Arif, Mahmud, 2012, Pendidikan Agama Islam InklusifMultikulturalisme, Jurnal Pendidikan Islam Vol.1 N0.1, Juni 2012/1433.

Al Wizar, 2015, Pemikiran Pendidikan Al Ghazali, Jurnal Potensia Vol.14 Edisi 1 Januari-Juni 2015, Hal 140-141

Direktorat Jenderal Pembelajaran dan Kemahasiswaan Kementrian Riset, Teknlogi dan Pendidikan Tinggi R I, (2016), Pendidikan Agama Islam untuk PT, Cetakan 1. 
Ghazali, 2016, “Tasawuf Al Ghazali dalam Ihya' 'Ulum Al Din", makalah Seminar Nasional Imam Ghazali: "Pemikiran dan Pengaruhnya Terhadap Islam Nusantara dan Peradaban Dunia", IAIIG Cilacap pada tanggal 3 April 2016

Hazen, Ibnu (Ed), (2015), 100 Ulama Dalam Lintas Sejarah NU, (Jakarta: Lembaga Ta'mir Mesjid-PBNU, 2015).

Hermawan, Asep, 2016, Konsep Belajar dan Pembelajaran Menurut Al Ghazali, Studia Didaktika, Jurnal Ilmiah Pendidikan, Vol.10 N0.1 tahun 2016

Maduqi, Irwan, 2013, Deradikalisasi Pendidikan Islam Berbasis Khasanah Pesantren, jurnal Pendidikan Islam Vol.1, Juni 2013/1434, hlm.10-12.

Machali, Imam, 2013, Peace Education Dan Deradikalisasi Agama, Jurnal Pendidikan Islam Vol.II, N0 1, Juni 2013/1434. hlm. 48-49

Muhadjir, Noeng.2000. Metodologi Penelitian Kualitatif. Yogyakarta: Rake Sarasin

Muqoyyidin, Andik Wahyun, 2013, Membangun Kesadaran Inklusif-Multikultural Untuk Deradikalisasi Pendidikan Islam, Jurnal Pendidikan Islam Vol.II, Noor 1, Juni 2013/1434. Hlm.134.

Nurudin, 2015, Perbandingan Pengelolaan Pendidikan Agama Pada Sekolah di Indonesia dan Sekolah Republik Indonesia Tokyo, Jurnal Pendidikan Islam. Vol.IV.Nomor 1, Juni 2015/1436, hal.9

Soleh, Akhmad, 2014, Kebijakan PT Negeri Yogyakarta Terhadap Penyandang Disabiltas, Jurnal Pendidikan Islam Vol.III Nomor 1, Juni 2014/1435, hlm. 13

Schumacher, James H McMillan and Sally, 2001, Research In Education. A Conceptual Introduction. New York: Addison Wesley Longman.Inc.

Undang-Undang Republik Indonesia Nomor .20 tahun 2003 tentang Sistem Pendidikan Nasional. Duta Nusindo, Semarang 
Undang-Undang Republik Indonesia Nomor .12 Tahun 2012 tentang Pendidikan Tinggi

Zulfa, Umi. 2011. Metodologi Penelitian Sosial. Edisi Revisi. Yogyakarta: Cahaya Ilmu. , 2017, Model Pembelajaran Unggulan, Cilacap: Ihya Media.

, 2013, "Model Pembelajaran :SICI" Alternatif Model Pembelajaran IRE Unggulan", Nadwa.Volume 7.Nomor 1, April 2013: 118-123. 